\title{
PERLINDUNGAN HUKUM BAGI DOKTER DAN PASIEN DALAM MELAKUKAN INFORMED CONSENT PADA TINDAKAN C-SECTION TANPA INDIKASI MEDIS
}

\author{
Yohana Rosita Dewi Mariyani \\ Universitas Sebelas Maret \\ E-mail: yohanardm@mail.com
}

\begin{abstract}
In recent years, Caesarean section without medical indication seems to be a trend of medical action that occurs in society. Many factors cause this to happen. Among them, so that the fetus can be born according to the desired date of the parents, or based on other factors outside of medical conditions. In the implementation of a Caesarean section, medical consent before the Caesarean section is performed is still very necessary to minimize the medical risk that the patient is suspected of experiencing. In addition, with the existence of medical approval before the Caesarean section is carried out, it is hoped that it will also be able to provide legal protection to patients and doctors both preventively and repressively.
\end{abstract}

Keywords: Legal Protection, Informed Consent, Medical Treatment, Cesarian Section

\begin{abstract}
Abstrak
Beberapa tahun belakangan ini, tindakan Operasi Caesar tanpa indikasi medis seolah menjadi sebuah trend tindakan medis yang terjadi didalam masyarakat. Banyak faktor yang menyebabkan hal demikian terjadi. Diantaranya, agar janin bisa dilahirkan sesuai tanggal keinginan dari orang tua, ataupun berdasarkan faktor lainnya diluar ketentuan medis. Dalam pelaksanaan upaya Operasi Caesar, tindakan persetujuan medis sebelum upaya Operasi Caesar ini dilakukan masih sangat diperlukan guna meminimalisir resiko medis yang diduga akan dialami oleh pasien. Selain itu, dengan adanya tindakan persetujuan medis sebelum upaya operasi Caesar ini dilaksanakan, diharapkan juga turut mampu memberi perlindungan hukum pada pasien dan dokter baik secara preventif maupun represif.
\end{abstract}

Kata Kunci : Perlindungan Hukum, Persetujuan Medik, Operasi Caesar, Tindakan Medis

\section{A. Pendahuluan}

Dalam sebuah proses persalinan terdapat dua macam proses, yakni proses persalinan secara normal dan persalinan yang dilakukan dengan suatu upaya atau tindakan medis. Persalinan yang dilakukan dengan upaya demikian disebabkan karena adanya indikasi medik untuk dilakukan suatu operasi Caesar.

Dalam beberapa tahun terakhir ini, tindakan operasi Caesar sudah tidak lagi asing dalam kehidupan masyarakat kita saat ini, operasi Caesar merupakan salah satu jenis intervensi medis dalam proses persalinan yang muncul seiring dengan berkembangnya teknologi.

Caesaria Section atau yang lebih dikenal oleh orang awam sebagai operasi saesar merupakan sebuah upaya yang diperlukan dalam membantu proses persalinan yang tidak bisa dijalani secara normal, dikarenakan adanya suatu kendala kesehatan yang dialami oleh ibu atau janin. Upaya ini dapat diartikan sebagai pembedahan untuk melahirkan janin 
dengan cara membuka dinding perut dan dinding uterus atau vagina atau bisa juga suatu histeromi dengan tujuan untuk melahirkan janin dari dalam Rahim. Namun demikian, pada saat ini upaya caesaria section bukan lagi suatu upaya yang dilakukan karena pertimbangan medis, melainkan juga menjadi permintaan pasien meskipu pasien tidak memiliki kendala kesehatan. Upaya caesaria section, memungkinkan seorang wanita yang akan melakukan proses persalinan untuk merekayasa hari persalinan, sesuai kehendaknya. ${ }^{1}$

Hubungan hukum yang terjadi diantara tenaga kesehatan/dokter dengan pasien seringkali jadi bahan perbincangan hangat bagi masyarakat. Entah itu hanya pembicaraan di kalangan tenaga medis, entah itu pembicaraan di kalangan praktisi hukum, ataupu dikalangan masyarakat yang selalu berkaitan dengan perawatan medis.

Munculnya pembicaraan tersebut dikarenakan tidak sedikit media cetak maupun media elektronik seringkali peristiwa hukum yang diduga disebabkan oleh kesalahan yang terjadi karena perawatan medis. Oleh karenanya sering dicari terkait bagaimana peyebab peristiwa itu terjadi dan siapakah yang nantinya diduga wajib bertanggung jawab bila terjadinya kematian atau kecacatan pada pasien dalam suatu peristiwa perawatan medis. Sampai pada akhirnya pembicaraan tersebut sampa kepada Informed Consent.

Informed Consent secara harafiah terdiri dari dua kata yaitu informed dan consent. Informed berarti telah mendapat informasi atau penjelasan; sedangkan yang dimaksud dengan consent memberi persetujuan atau memberikan izin. Dengan demikian yang dimaksud Informed Consent adalah suatu persetujuan yang diberikan setelah mendapatkan informasi. Berdasarkan Permenkes Nomor 585/MEN.KES/PER/X/1989 Pasal 1 huruf a menyatakan persetujuan tindakan medik adalah persetujuan yang diberikan oleh pasien atau keluarganya atas dasar penjelasan mengenai tindakan medik yang akan dilakukan terhadap pasien tersebut.

Dari sudut pandang dokter, persetujuan tindakan medis sangat berkaitan dengan kewajiban dokter dalam memberikan informasi kepada pasien dan tindakan tersebut juga merupakan kewajiban untuk melakukan tindakan medic sesuai dengan standart profesi kedokteran. Suatu informed consent bisa dikatakan sah apabila telah memenuhi 3 unsur seebagai berikut $:^{2}$

1. Keterbukaan informasi yng cukuo diberikan oleh dokter;

2. Kompetensi pasien dalam memberikan persetujuan;

3. Kesukarelaan pasien dalm memberikan persetujuan;

Berdasarkan pemikiran dari Philipus M. Hadjon, ${ }^{3}$ yang dimaksud sebagai Perlindungan Hukum adalah suatu perlindungan yang diberikan pada tiap-tiap subjek hukum tanpa terkecuali, baik yang bersifat preventif mupun bersifat represif, baik secara tertulis mupun tidak tertulis. Dengan kata lain, perlidunngan hukum merupakan suatu gambaran dari fungsi hukum, yakni konsep di mana hukum tersebut dapat memberikan suatu keadilan, ketertiban, kepastian, kemanfaatan, kedamaian, ketentraman bagi segala kepentingan umat manusia yang di dalam masyarakat.

1 Juditha I, Cynthia I. Tips Praktis bagi Wanita Hamil. Jakarta: Forum Kita; 2009

2 Soejatmiko. Masalah Medik dalam Malpraktek Yuridik, Kumpulan Makalah, RSUD, 2001, hal. 3

3 Philiphus M. Hadjon dalam Ribka Djula, 2010, "Perjanjian Waralaba Sebagai Sarana Alih Teknologi”, (Tesis Magister Ilmu Hukum, Universitas Mataram), hal. 11 
Hubungan hukum yang terjadi antara dokter dan pasien, harus memiliki landasan hukum yang kuat. Tujuannya adalah untuk dapat menghindari suatu sengketa medis dari adanya suatu tindakan medis yang diberikan kepada pasien.

Pelaksanaan tindakan Caesar Section baik dikarenakan indikasi medis atau tanpa indikasi medis, haruslah memperoleh persetujuan dari pasien atau keluarganya yang diwujudkan dalam Informed Consent. Agar nantinya bila terindikasi adanya kesalahan dalam suatu perawatan medis dapat diketahui apakah kesalahan tersebut terletak pada pasien yang tidak mematuhi prosedur yang terdapat pada informed consent atau terletak pada kelalaian dokter. Selain itu, informed consent juga bisa menjadi landasan dalam pemberian perlindungan hukum bagi pasien bila terjadi suatu peristiwa hukum bagi dokter maupun pasien.

Berdasarkan uraian yang peneliti sampaikan diatas, peneliti tertrik untuk meneliti perlindungan hukum dalam melakukan informed consent dengan judul "Perlindungan Hukum Bagi Dokter Dan Pasien Dalam Melakukan Informed Consent Pada Tindakan C-Section Tanpa Indikasi Medis”.

\section{B. Pembahasan}

\section{Pengertian Informed Consent Terkait Tindakan C-Section Tanpa Indikasi Medis}

Istilah caesaria section atau c-section berasal dari bahasa latin cadere yang berarti tindakan memotong dan menyayat. Dalam ilmu obsetrik, istilah cadere mengacu pada suatu tindakan pembedahan dengan tujuan melahirkan bayi dengan membuka dinding perut dan rahim ibu. ${ }^{4}$

Persalinan dengan proses caesaria section awalnya ditujukan utuk indikasi medis tertentu, yang terbagi atas indikasi untuk ibu dan indikasi untuk si bayi itu sendiri. Proses persalinan ini dilakukan sebagai suatu tindakan alternative persalinan ketika proses persalinan secara normal dirasa tidak bisa lagi untuk dilakukan..

Setiap melakukan suatu tindakan medis, tentunya harus berlandaskan pada diagnosis medis. Terlebih pada tindakan medis dengan resiko tinggi. Salah satunya adalah Caesaria Section. Caesaria Section pada awalnya dilakukan dengan adanya kelainan pada passage sehingga kelahiran tidak dapat melalui jalan normal. Passage sendiri merupakan salah satu faktor dalam persalinan yang meliputi bagian tulang panggul, serviks, vagina, dan dasar panggul. Secara spesifik, indikasi medis dapat dilaksanakan tindakan caesaria section meliputi: ${ }^{5}$

a. Indikasi Fetus/Janin;

Kondisi fetus dalam kandungan yang dapat menunjukkan kondisi yang mengarah pada section, ykni adanya infusiensi pada plasenta. Dalam kasus demikian, keputusan untuk melakukan persalinan dengan jalan section dapat diambil sebelum terjadinya proses persalinan. ${ }^{6}$

4 Todman D. 2007. A History of Caesarean Section: From Ancient World to The Modern Era. Australian and New Zealand Journal of Obstet and Gynaecol, 47, hlm. 357

5 Gerhard Martius, “Operative Obestectris : Indication And Technique”, diterjemahkan Petrus Andrianto, Bedah Kebidanan, Ed.12 (Jakarta:EGC,1997), hlm.101

6 Gerhard Martius, Ibid, hlm. 102 
Selain itu, terdapat kondisi dimana prolapses tali pusat dan korioamniotis yang dapat membahayakan fetus. Diagnosis medis ini diawali oleh demam tinggi yang disertai dengan cairan amnion yang berbau busuk. Keadaan lain dimana termasuk di dalamnya beresiko pada fetus adalah kondisi gawat janin akibat air ketuban kering posisi bayi yang sungsang, pertumbuan janin yang kurang baik dan sebagainya. Secara spesifik, keadaan tersebut meliputi $;^{7}$

1) Plasenta Previa;

2) Ketidakseimbangan antara tulang panggul Ibu dan ukuran bayi;

3) Ibu mengalami preeclampsia;

4) Janin dalam posisi sungsang atau melintang;

5) Bayi terlilit tali pusar;

6) Postmature;

b. Indikasi Ibu

Indikasi Ibu bertujuan untuk menentukan apakah cukup beresiko dalam melakukan proses kelahiran secara normal. Hal ini dapat ditunjukkan dengan pemberian skor yang jadi pertimbangan dokter dalam penentuan tindakan medis selanjutnya. Indikasi terhadap Ibu, dapat diklasifikasikan menjadi :

1) Usia Ibu;

2) Riwayat penyakit;

3) Diabetes Melitus;

4) Letak plasenta ibu menutupi jalan lahir janin.

Selain indikasi tersebut, terdapat indikasi lain, yaitu misalnya setelah 3 jam dibimbing melahirkan normal ternyata hasilnya nihil, sementara sudah tidak memungkinkan lagi bila dilakukan dengan tindakan forceps, maka aternatif terakhir dalam melakukan proses persalinan adalah caesarea. ${ }^{8}$

Pada umumnya, tindakan Caesaria Section memiliki dua tipe utama, yaitu segmen atas dan segmen bawah. Secara teknis kedua tipe ini adalah sebagai berikut : 9

a. Segmen Atas;

Sebagaimana yang dimaksud dengan segmen atas pada proses persalinan caesarian section merupakan suatu pembedaan melalui sayatan vertical pada dinding perut, atau lebih dikenal dengan sayatan klasik. Jenis ini memungkinkan membuka ruang yang lebih besar sebagai jalan keluar dari janin tersebut. Namun, seiring dengan berkembangnya ilmu pengetahuan dan kemajuan teknologi, segmen ini sudah jarang dilakukan oleh dokter karena dianggap memiliki resiko tinggi terhadap proses kelahiran. Karena sering laki diperlukan sayatan yang lebih besar yang disebabkan ole bayi sering dilahirkan dengan bokong terlebih dahulu.

7 Ida Bagus Gede Manuaba, Operasi Kebidanan Dan Keluarga Berencana Untuk Dokter Umum, (EGC;Jakarta,1999), hlm. 127

8 Kasdu, Dini. 2003. Operasi Caesar Masalah dan Solusinya. Jakarta: Puspa Swara

9 James R.Scott,"Danfort's Handbook of Obstetrics And Gynekology”, diterjemahkan TMA Chalik dan Huriawati Hartanto, Danfort Buku Saku Obsetri dan Ginekologi, (Jakarta:Widya Medika, 2002), hlm. 308 
b. Segmen Bawah

Pembedahan dengan segmen bawah meliputi dua jenis, diantaranya :

1) Insisi Melintang;

Yaitu tindakan dengan melakukan sayatan secara mendatar pada bawa uterus, kemudian sayatan ini dilebarkan dengan jari-jari tangan yang terhenti di daerah pembuluh darah uterus.

2) Insisi Membujur;

Insisi ini ini hampir sama dengan sayatan pada posisi melintang. Hanya saja letak dari sayatan ini menjadi vertical dibawah rahim.

Seperti yang telah peneliti uraikan diatas, Caesarea Section dilakukan dengan cara membuat sayatan melintang diperut dan rahim Ibu sesuai dengan kondisi dan kebetuhan yng diperlukan dalam proses tindakan medisnya. Pada saat dilakukannya tindakan caesaria section tentunya terdapat beberapa keuntungan yang didapat baik bagi Ibu maupun janin, diantaranya adalah : ${ }^{10}$

a. Bisa memilih sendiri waktu persalinan;

b. Menurunkan risiko cedera kelahiran, seperti distosia bahu (tersangkutnya bahu janin dan tidak dapat dilahirkan) atau janin mengalami patah tulang;

c. Menurunkan risiko terjadinya inkontinensia urine dan prolaps organ panggul (turun peranakan).

d. Lebih dianjurkan untuk ibu hamil yang memiliki penyulit atau komplikasi kehamilan.

Meski memiliki keunggulan, metode persalinan caesar juga memiliki kekurangan atau risiko, yaitu: ${ }^{11}$

a. Proses pemulihan dan rawat inap di rumah sakit lebih lama dibandingkan persalinan normal.

b. Luka operasi menimbulkan bekas luka dan rasa nyeri. Proses pemulihannya pun tergolong lama, bisa berminggu-minggu bahkan hingga beberapa bulan.

c. Terbatas melakukan aktivitas selama setidaknya 6 minggu setelah operasi.

d. Terjadinya komplikasi akibat anestesi, seperti mual, mengantuk, pusing, sakit kepala parah, hingga kerusakan saraf.

e. Terjadinya komplikasi akibat operasi, seperti penyumbatan pembuluh darah, infeksi, perdarahan, hingga adhesi (tumbuhnya jaringan parut yang membuat organ di dalam perut menempel satu sama lain).

f. Kemungkinan kembali melakukan operasi caesar di proses persalinan selanjutnya.

g. Plasenta previa di kehamilan selanjutnya.

10 Kevin Adrian, "Melahirkan Normal Vs Caesar: Ini Manfaat dan Risikonya" dikutip pada https://www.alodokter. com/melahirkan-normal-vs-caesar-ini-manfaat-dan-risikonya\#: : text=Meski\%20memiliki\%20keunggulan\%2C\%20 metode\%20persalinan,bekas\%20luka\%20dan\%20rasa\%20nyeri , diakses pada 15 Noveber 2020.

11 Kevin Adrian, Ibid 
Biasanya operasi ini ditempuh karena persalinan normal berisiko membahayakan keselamatan ibu dan bayinya. Berikut ini adalah beberapa hal yang sering menjadi penyebab diperlukannya operasi caesar:

a. Ibu memiliki kondisi medis yang tidak memungkinkannya untuk melahirkan secara normal, misalnya diabetes, preeklamsia, herpes di jalan lahir, HIV, penyakit jantung, atau plasenta previa;

b. Ibu akan melahirkan bayi kembar.;

c. Ukuran bayi cukup besar atau berada dalam posisi sungsang.

d. Ibu memiliki panggul yang sempit.

e. Proses pembukaan jalan lahir yang lambat.

f. Pernah menjalani operasi caesar sebelumnya.

Permintaan persalinan caesar semakin tahun semakin meningkat. Meski risikonya lebih besar ketimbang persalinan normal, nyatanya tidak sedikit ibu hamil yang sengaja meminta persalinan caesar, bisa karena tanggal cantik atau justru karena tak ingin merasakan sakit saat melahirkan. Operasi caesar merupakan prosedur bedah yang digunakan untuk melahirkan dengan membuat sayatan di perut ibu dan sayatan kedua di rahim ibu. Persalinan caesar mungkin direncanakan sebelumnya jika Anda mengalami komplikasi kehamilan. Sayangnya, kini persalinan caesar seolah menjadi tren yang sengaja dipilih ibu hamil meski tanpa indikasi medis yang jelas. ${ }^{12}$

Persalinan melalui operasi SC pada kesempatan tertentu dilakukan tanpa indikasi medis yang kuat berdasarkan permintaan pasien. Keputusan ini dilakukan tenaga medis dengan alasan karena memilih cara persalinan adalah hak pasien, berbuat baik terhadap pasien, mempertimbangan kondisi psikis pasien, berniat adil terhadap pasien. Menghadapi hal ini tenaga medis akan memberikan edukasi kepada pasien dengan menjelaskan kelebihan dan kekurangan atau risiko tindakan SC dan komplikasinya, termasuk rencana kehamilan berikutnya. Tenaga medis tetap menghormati keputusan pasien dan keluarga, selanjutnya pasien akan membuat permohonan tertulis untuk dilakukan tindakan SC yang ditandatangani oleh pasien dan keluarga sebagai saksi. ${ }^{13}$

Persalinan melalui SC tanpa indikasi medis yang terjadi karena keinginan calon ibu juga ba-nyak yang disebabkan oleh masalah psikologis sebelum melahirkan, misalnya karena ibu merasakan kekhawatiran yang berlebih jika melalui persalinan secara normal sehingga secara tidak terencana menginginkan operasi caesaria section. ${ }^{14}$

Informed Consent secara harafiah terdiri dari dua kata yaitu informed dan consent. Informed berarti telah mendapat informasi atau penjelasan; sedangkan yang dimaksud dengan consent memberi persetujuan atau memberikan izin. Dengan demikian yang dimaksud Informed Consent adalah suatu persetujuan yang diberikan setelah mendapatkan informasi. Berdasarkan Permenkes Nomor 585/MEN.KES/PER/X/1989 pasal 1 huruf a menyatakan persetujuan tindakan medik adalah persetujuan yang

12 Mr/Vit, "Banyak Ibu Minta Melahirkan Secara Sesar Ini Tanggapan Dokter", dikutip pada https://health.detik.com/ibuhamil/d-2565443/banyak-ibu-minta-operasi-caesar-saat-melahirkan-ini-tanggapan-dokter, diakses pada 15 November 2020

13 Dumilah Ayuningtyas ett All, Etika Kesehatan Pada Persalinan Melaui Sectio Caesarea Tanpa Indikasi Medis", Jurnal MKMI, Vol.14 No.1, Maret 2018, hlm. 13

14 Dumilah Ayunungtyas et all, Ibid, hlm. 13 
diberikan oleh pasien atau keluarganya atas dasar penjelasan mengenai tindakan medik yang akan dilakukan terhadap pasien tersebut.

Di Indonesia terdapat ketentuan informed consent yang diatur antara lain pada Peraturan Pemerintah Nomor 18 Tahun 1981dan Surat Keputusan PB IDI Nomor 319/ $\mathrm{PB} / \mathrm{A} 4 / 88$, yaitu tentang pernyataan IDI tentang informed consent tersebut, adalah : ${ }^{15}$

a. Manusia dewasa sehat jasmani dan rohani berhak sepenuhnya menentukan apa yang hendak dilakukan terhadap tubuhnya. Dokter tidak berhak melakukan tindakan medis yang bertentangan dengan kemauan pasien, walaupun untuk kepentingan pasien sendiri.

b. Semua tindakan medis (diagnotik, terapeutik maupun paliatif) memerlukan inform concent secara lisan maupun tertulis.

c. Setiap tindakan medis yang mempunyai resiko cukup besar, mengharuskan adanya persetujuan tertulis yang ditandatangani pasien, setelah sebelumnya pasien memperoleh informasi yang kuat tentang perlunya tindakan medis yang bersangkutan serta resikonya.

d. Untuk tindakan yang tidak termasuk dalam butir 3 hanya dibutuhkan persetujuan lisan atau sikap diam.

e. Informasi tentang tindakan medis harus diberikan kepada pasien, baik diminta maupun tidak diminta oleh pasien. Menahan informasi tidak boleh, kecuali bila dokter menilai bahwa informasi tersebut dapat merugikan kepentingan kesehatan pasien. Dalam hal ini dokter dapat memberikan informasi kepada keluarga terdekat pasien. Dalam member informasi kepada keluarga terdekat dengan pasien, kehadiran seorang perawat/ paramedic lainnya sebgai saksi adalah penting.

f. Isi informsasi mencakup keuntungan dan kerugian tindakan medis yang direncanakan, baik diagnostic, terapeutik maupun paliatif. Informasi biasanya diberikan secara lisan, tetapi dapat pula secara tertulis.

Ruang lingkup dan materi informasi yang diberikan tergantung pada pengetahuan medis pasien saat itu. Jika memungkintkan pasien juga diberitahu mengenai tanggung jawab orang lain yang berperan serta dalam pengobatan pasien.

Biasanya informed consent ini harus meliputi : ${ }^{16}$

a. Dokter harus menjelaskan pada pasien mengenai tindakan, terapi, dan penyakitnya;

b. Pasien harus diberitahu tentang hasil terapi yang diharapkan dan seberapa besar kemungkinan keberhasilannya;

c. Pasien harus diberitahu mengenai beberapa alternative yang ada dan akibat apabila penyakit tidak diobati;

d. Pasien harus diberitahu mengenai risiko apabila menerima atau menolak terapi.

PMK Nomor 290/ MenKes /Per/III / 2008 menyebutkan bahwa informed consent merupakan suatu persetujuan yang diberikan oleh pasien atau keluarga terdekat setelah mendapat penjelasan secara lengkap mengenai tindakan kedokteran atau kedokteran

15 M Yusuf hanafiah dan amri amir, 1999, Etika kedokteran dan hukum kesehatan, EGC, Jakarta, hal. 13.

16 Soejatmiko., Opcit, hlm.4 
gigi yang akan dilakukan terhadap pasien. Dalam menyetujui tindakan tersebut, sebelumnya tenaga kesehatan yang bersangkutan harus memberikan pernjelasan terlebih dahulu terkait hal-hal yang berkaitan dengan pelayanan atau tindakan yang akan dilakukan.. ${ }^{17}$ Dipandang dari kedudukan para pihak, maka informed consent merupakan syarat subjektif untuk terjadinya transaksi terapeutik yang bertumpu pada dua jenis hak asasi yang bersifat hak dasar dari setiap diri manusia, yaitu hak asasi atas informasi dan hak asasi untuk menentukan nasib sendiri. ${ }^{18}$

\section{Perlindungan Hukum bagi Pasien dan Dokter dalam Melakukan Informed Consent pada Tindakan C-Section Tanpa Indikasi Medis}

Padadasarnyaperlindunganhukum dapatdibedakanmenjadiduayaitu ${ }^{19}$, perlindungan hukum yang preventif dan perlindungan hukum yang represif. Perlindungan hukum yang preventif bertujuan untuk mencegah terjadinya sengketa, sedangkan perlindungan hukum yang represif bertujuan untuk menyelesaikan sengketa.

Menurut pengertianya, Perlindungan Hukum merupakan segala upaya yang dapat menjamin adanya kepastian hukum, sehingga mampu memberikan perlindungan hukum kepada pihak-pihak yang melakukan tindakan hukum. Setiono menjelaskan, Perlindugan Hukum merupakan suatu upaya untuk melindungi masyarakat dari perbuatan sewenang-wenang penguasa yang tidak sesuai dengan atran hukum, dalam rangka mewujudkan ketertiban dan ketentraman sehingga memungkinkan manusia untuk menikmati martabatnya sebagai manusia. ${ }^{20}$

Dalam pelaksanaan Caesarian Section tentunya terdapat beberapa hak dan kewajiban yang perlu diketahui baik dari pihak dokter dan dan pasien, diantaranya $:{ }^{21}$

a. Hak dan Kewajiban Pasien

Hak pasien mencakup hak atas informasi medik, hak memberikan persetujuan tindak medik, hak untuk memilih dokter dan rumah sakit, hak atas rahasia medik, hak untuk menolak pengobatan atau perawatan secara tindak medik, hak untuk mendapat penjelaskan lain (second opinion), serta hak untuk mengetahui isi rekam medik. Selanjutnya kewajiban pasien antara lain: kewajiban memberikan informasi medik, mentaati petunjuk atas nasehat dokter, memenuhi aturan-aturan pada sarana kesehatan, memberikan imbalan jasa kepada dokter, berterus terang, serta meyimpan rahasia pribadi dokter yang diketahuinya. Kewajiban-kewajiban pasien di atas sesuai dengan yang diatur dalam Pasal 43 UU No 29 tahun 2004 tentang Praktik Kedokteran, yang meliputi: memberi informasi yg lengkap dan jujur tentang masalah kesehatannya, mematuhi nasihat dan petunjuk dokter dan

17 Ida Ayu Sri Kusuma Wardhani, 2014, "Implementasi Persetujuan Tindakan Kedokteran (Informed Consent) dalam Perjanjian Terapeutik oleh Tenaga Kesehatan terhadap Pasien Rumah Sakit di Provinsi Bali”, Jurnal Magister Hukum Udayana, Vol 3 No.1, h.7

18 H. Muntaha, 2017, Hukum Pidana Malpraktik: Pertanggungjawaban dan Penghapus Pidana, Sinar Grafika, Jakarta, h.24.

19 Philipus M. Hadjon, 2007, Perlindungan Hukum Bagi Rakyat Indonesia, Sebuah Studi Tentang Prinsip-Prinsipnya, Penanganannya Oleh Pengadilan Dalam Lingkungan Peradilan Umum Dan Pembentukan Pengadilan Administrasi, Edisi Khusus, Tanpa Tempat, Peradaban, hal. 2.

20 Setiono, Rule of Law (Supremasi Hukum). (Surakarta: Magister Ilmu Hukum Program Pascasarjana Universitas Sebelas Maret, 2004), hlm.3

21 Erdward Pratama, Tanggun Jawab Terhadap Pasien Dalam Operasi Bedah Caesar Di RS. Moewardi Surakarta, (Surakarta, Universitas Muammadiyah Surakarta, Fakultas Hukum), 2016, hlm.13 
dokter gigi, mematuhi ketentuan yang berlaku di saryankes, dan memberi imbalan jasa atas pelayanan yang diterima.

b. Hak dan Kewajiban Dokter

Hak-hak dokter antara lain adalah sesuai dengan hak-hak dokter yang diatur pada Pasal 50 Undang-Undang Nomor 29 Tahun 2004 tentang Praktik Kedokteran bahwa dokter dalam melaksanakan praktek kedokteran mempunyai hak, yaitu: memperoleh perlindungan hukum sepanjang menjalankan tugas sesuai standar profesi dan standar prosedur operasi, memperoleh informasi yang lengkap dan jujur dari pasien atau keluarganya, serta menerima imbalan jasa. Hak-hak dokter di atas sesuai literatur yang diperoleh dari Surat Edaran Dirjen Pelayanan Medik Nomor YM.02.04.3.5.2504 tanggal 10 Juni 1997 menyebutkan dokter memiliki hak, yaitu: Mendapat perlindungan hukum dalam melaksanakan tugas sesuai dengan profesinya, memperoleh informasi yang lengkap dan jujur dari pasien, hingga hak mendapatkan imbalan atas jasa profesi. Kewajiban dokter tersebut sesuai dengan Surat Edaran Dirjen Pelayanan Medik Nomor YM.02.04.3.5.2504 tanggal 10 Juni 1997 menyebutkan dokter memiliki kewajiban, yaitu memberikan pelayanan medis sesuai dengan standar profesi dan menghormati hak pasien, memberikan informasi yang cukup tentang perlunya tindakan medis dan resiko yang dapat terjadi serta memenuhi hal-hal yang telah disepakati yang telah dibuatnya.

Perlindungan Hukum bagi dokter dan pasien, sejatinya telah diatur dalam UndangUndang Nomor 29 Tahun 2004 tentang Praktik Kedokteran, diantaranya adalah :

a. Memberikan perlindungan kepada pasien;

b. Mempertahankan dan meningkatkan mutu dari pelayanan medis yang diberikan oleh dokter dan dokter gigi;

c. Memberikan kepastian hukum pada masyarakat, dokter dan dokter gigi.

Dalam melakukan upaya Caesaria Section tanpa indikasi medis, tentunya dokter melakukan kewajibannya dalam menyampaikan terkait penjelasan dari upaya medis tersebut serta juga menyampaikan resiko-resiko yang nantinya bisa terjadi pada pasien, sekalipun pasien yang meminta untuk dilakukannya upaya medis tersebut.

Pasien disini juga berkewajiban untuk mentaati apa saja hal-hal yang telah dijelaskan oleh dokter terkait proses dari persalinan Caesar ini dalam upaya utuk menghindari terjadinya kesalahan atau sengketa medis.

Karena pada umumnya banyak faktor yang mampu mempengaruhi berhail tidaknya suatu upaya medis ini yang tidak hanya berasal dari kelalaian dokter. Melainkan bisa jadi dikarenakan pasien tidak mematuhi apa yang telah disampaikan oleh dokter.

Perlindungan Hukum preventif yang bisa diberikan kepada dokter dalam memberikan suatu jaminan agar tidak terjadinya suatu kesalahan tindakan medis adalah dengan menggunakan Stadart Operasional Prosedur dan Starndart Pelayanan Minimal. Selain itu, bila nantinya ada resiko yang muncul paska tindakan Caesaria Section pada pasien, pihak pemberi pelayanan kesehatan wajib memberikan perlinungan represiv yang bertujuan untuk menyelesaikan masalah tersebut diluar pengadilan dengan cara diadakannya pembicaraan kedua belah pihak atau melalui fasilitasi dan mediasi. 
Pun dalam memperikan perlindungan hukum pada Pasien, bila terjadi suatu dugaan kesalahan medis, pemberi pelayanan kesehatan juga wajib menyediakan layanan pengaduan secara adil dan tanpa adanya tindakan diskriminasi.

\section{Kesimpulan}

Dalam melakukan suatu upaya medis yakni Caesaria Section, baik dengan indikasi medis atau tanpa indikasi medis, Tenaga Kesehatan diwajibkan untuk memberikan informed consent terkait proses tindakan medis dan resiko-resiko yang bisa terjadi pada proses Caesaria Section tersebut. Selain itu, pasien juga berkewajiban mematuhi ketentuan yang tertuang dalam informed consent sehingga diharapkan dapat meminimalisir terjadinya kesalahan tindakan medis.

Perlindungan Hukum bagi dokter dan pasien dalam tindakan caesaria section berdasarkan informed consent yang telah disepakati keduanya, seharusnya juga diberikan jaminan oleh penyedia layanan kesehatan dalam hal ini rumah sakit atau klinik, tempat dimana terjadinya tindakan tersebut jika nantinya terjadi suatu tindakan kesalahan medis yang tidak terduga.

\section{Daftar Pustaka}

\section{Buku}

Gerhard Martius, "Operative Obestectris : Indication And Technique”, diterjemahkan Petrus Andrianto, Bedah Kebidanan, Ed.12 (Jakarta:EGC,1997)

H. Muntaha, Hukum Pidana Malpraktik: Pertanggungjawaban dan Penghapus Pidana, Sinar Grafika, Jakarta, 2007

Ida Bagus Gede Manuaba, Operasi Kebidanan Dan Keluarga Berencana Untuk Dokter Umum, (EGC;Jakarta,1999)

James R.Scott,"Danfort's Handbook of Obstetrics And Gynekology", diterjemahkan TMAChalik dan Huriawati Hartanto, Danfort Buku Saku Obsetri dan Ginekologi, (Jakarta:Widya Medika, 2002)

Juditha I, Cynthia I. Tips Praktis bagi Wanita Hamil. Jakarta: Forum Kita; 2009

M Yusuf hanafiah dan amri amir, etika kedokteran dan hukum kesehatan, EGC, Jakarta, 1999

Kasdu, Dini. Operasi Caesar Masalah dan Solusinya. Jakarta: Puspa Swara. 2003

Todman D. A History of Caesarean Section: From Ancient World to The Modern Era. Australian and New Zealand Journal of Obstet and Gynaecol, 2007

Philipus M. Hadjon, 2007, Perlindungan Hukum Bagi Rakyat Indonesia, Sebuah Studi Tentang Prinsip-Prinsipnya, Penanganannya Oleh Pengadilan Dalam Lingkungan Peradilan Umum Dan Pembentukan Pengadilan Administrasi, Edisi Khusus, Tanpa Tempat, Peradaban 


\section{Jurnal}

Dumilah Ayuningtyas ett All, Etika Kesehatan Pada Persalinan Melaui Sectio Caesarea Tanpa Indikasi Medis", Jurnal MKMI, Vol.14 No.1 , Maret 2018.

Erdward Pratama, Tanggun Jawab Terhadap Pasien Dalam Operasi Bedah Caesar Di RS. Moewardi Surakarta, (Surakarta, Universitas Muammadiyah Surakarta, Fakultas Hukum), 2016

Ida Ayu Sri Kusuma Wardhani, “Implementasi Persetujuan Tindakan Kedokteran (Informed Consent) dalam Perjanjian Terapeutik oleh Tenaga Kesehatan terhadap Pasien Rumah Sakit di Provinsi Bali”, Jurnal Magister Hukum Udayana, Vol 3 No.1, 2014

Philiphus M. Hadjon dalam Ribka Djula, 2010, “Perjanjian Waralaba Sebagai Sarana Alih Teknologi”, (Tesis Magister Ilmu Hukum, Universitas Mataram)

Setiono, Rule of Law (Supremasi Hukum). (Surakarta: Magister Ilmu Hukum Program Pascasarjana Universitas Sebelas Maret, 2004)

Soejatmiko. Masalah Medik dalam Malpraktek Yuridik, Kumpulan Makalah, RSUD, 2001

\section{Internet}

Kevin Adrian, "Melahirkan Normal Vs Caesar: Ini Manfaat dan Risikonya" dikutip pada https://www.alodokter.com/melahirkan-normal-vs-caesar-ini-manfaat-danrisikonya\#: :text=Meski\%20memiliki\%20keunggulan $\% 2 \mathrm{C} \% 20$ metode $\% 20$ persalinan,bekas\%20luka\%20dan\%20rasa\%20nyeri, diakses pada 15 Noveber 2020.

MIr/Vit, "Banyak Ibu Minta Melahirkan Secara Sesar Ini Tanggapan Dokter", dikutip pada https://health.detik.com/ibu-hamil/d-2565443/banyak-ibu-minta-operasi-caesar-saatmelahirkan-ini-tanggapan-dokter, diakses pada 15 November 2020 